\title{
Common variable immunodeficiency in a child. A case report
}

\author{
Andrey V. Kozlov, Tatiana A. Bykova, Anastasia S. Borovkova, Maria Yu. Averjanova, Varvara N. Ovechkina, \\ Elena V. Morozova, Ludmila S. Zubarovskaya, Nikolay N. Mamaev, Boris V. Afanasyev \\ R. Gorbacheva Memorial Research Institute of Children Oncology, Hematology and Transplantology, Chair of Hematology, \\ Transfusiology and Transplantation, First St. Petersburg State I. Pavlov Medical University, St. Petersburg, Russia
}

Dr. Andrey V. Kozlov, R. Gorbacheva Memorial Research Institute of Children Oncology, Hematology and Transplantology, Chair of Hematology, Transfusiology and Transplantation, First St. Petersburg State I. Pavlov Medical University, L. Tolstoy St. 6-8, 197022, St. Petersburg, Russian Federation
Phone: +7 (921) 3272879

E-mail: kozlovandrew@list.ru

\section{Summary}

Primary immunodeficiency syndromes are relatively rare medical conditions that are often misdiagnosed because of unspecific clinical presentation that mimics other more common diseases. Incidence of combined common variable immunodeficiency (CVID) is ca. 1 case per 30.000 European population. Usually, a delay of several years is observed between onset and diagnosis. CVID is the most frequent primary immunodeficiency after 4 years of life. The key symptom to establish the disorder is hypogammaglobulinemia.

The aim of this article is to demonstrate current trends in diagnostics of common variable immunodeficiency (CVID). The present case report describes a 10-year old girl with four major internationally approved criteria of common variable immunodeficiency (CVID), and specific lung involvement. Malignant conditions were excluded. NGS genetic study did not detect any gene mutation which could be responsible for CVID or related syndromes (ALPS, HLH). Hence, the CVID remains a diagnosis of exclusion. Despite replacement with intravenous immunoglobulins, the lung function in our patient continued to deteriorate that necessitated initiation of immunosuppressive treatment.

\section{Keywords}

Primary immunodeficiency, common variable immunodeficiency, diagnostic criteria, autoimmune complications.

\section{Introduction}

Primary immunodeficiency (PID) is a relatively rare medical condition that often mimics infectious, autoimmune or malignant diseases. Common variable immunodeficiency is the most common PID in children after 4 years of age and adults. Inherited CVID is revealed in only $20 \%$ of patients, showing autosomal recessive or autosomal dominant inheritance, while the rest of cases seem to occur sporadically [1]. In 2014, diagnostic criteria for CVID were revised by European Society of Immune Deficiencies (ESID), and its major features were established (Table 1). Those signs include increased susceptibility to infections, autoimmune manifestations, unexplained polyclonal lymphoproliferation, marked decrease of IgG and IgA with or without low IgM levels, poor antibody response to vaccines (and/or absent isohemagglu- tinins), low switched memory B cells. Secondary hypogammaglobulinemia should be excluded. Variable manifestations reflect a possibly different genetic background of the disease. At the present time, however, any specific mutations can be detected only in 30\% of CVID cases, even with such a comprehensive method as whole exome sequencing [2].

Incidence of CVID is ca. 1 case per 30.000 European population. Clinical manifestation of the disease may be at any age, with a first peak at 5 to 10 years and second, between 20 and 30 years. [3]. Common variable immunodeficiency is often diagnosed in children, being associated with high mortality in this group. [4]. Diagnostic criteria have been established, aiming to suspect PID in children including frequent infections of ears, sinuses and lungs, recurrent abscesses, persistent rash after first year of age, inefficiency of long-lasting treatment with antibiotics, inability to gain weight and 
Table 1. Revised ESID (2014) diagnostic criteria for CVID

\begin{tabular}{|l|}
\hline At least one of the following: \\
\hline - Increased susceptibility to infection \\
\hline - Autoimmune manifestations \\
\hline - Granulomatous disease \\
\hline - Unexplained polyclonal lymphoproliferation \\
\hline - Affected family member with antibody deficiency \\
\hline $\begin{array}{l}\text { AND marked decrease of lgG and marked decrease of IgA with or without low lgM levels (measured at least twice; }<2 \text { SD of the } \\
\text { normal levels for their age); }\end{array}$ \\
\hline AND at least one of the following: \\
\hline - Poor antibody response to vaccines (and/or absent isohemagglutinins); i.e., absence of protective levels despite vaccination \\
where defined \\
\hline - Low switched memory B cells (<70\% of age-related normal value) \\
\hline AND secondary causes of hypogammaglobulinemia have been excluded \\
\hline AND diagnosis is established after the fourth year of life (but symptoms may be present before) \\
\hline AND no evidence of profound T-cell deficiency, defined as two out of the following ( $y=$ year of life): \\
\hline C CD4 numbers/microliter: $2-6 y<300,6-12 y<250,>12 y<200$ \\
\hline \% \% Naive CD4: $2-6 y<25 \%, 6-16 y<20 \%,>16 y<10 \%$ \\
\hline . T-cell proliferation absent \\
\hline
\end{tabular}

growth, as well as family history of PID. Despite awareness of health care providers, a delay of several years is observed between first symptoms and diagnosis of PID [5]. This fact demonstrates that CVID is a diagnostic challenge, since it is often not considered. During diagnostic search, a wide spectrum of disorders may be considered at differential diagnosis. Detection of antibody deficiency is an important clue to suggest a CVID diagnosis. In general, CVID may be regarded as a diagnosis of exclusion. Autoimmune complications are, generally, common in PID and may manifest as initial symptoms in some cases. Only $25 \%$ of CVID patients present with common infections as the only symptom. In most cases, the CVID symptoms are associated with immune dysregulation [6]. Benign generalized hypertrophy of lymphoid tissues is more common in CVID than lymphoma [7]. Lungs are affected by infections and uncontrollable inflammation in up to $30 \%$, and early development of bronchiectasis is often a key to CVID diagnosis [8].

The main approaches to CVID management are IVIG replacement therapy, adequate infectious control and, in severe cases, immunosuppressive treatment. The only option to cure CVID is allogeneic hematopoietic stem cell transplantation, but its administration is rather limited in this clinical setting due to high toxicity. In case of severe and refractory hemolytic anemia, splenectomy may be a treatment option. Therefore, existence of life-saving management strategies, together with timely diagnosis increases chances for treatment success and underlines the necessity of awareness among medical staff [9].

In this report, we present a clinical case of a child with CVID which manifested with multiple autoimmune problems and progressive lung disease.

\section{Case description}

A 10-year-old female patient (PKD) with severe pancytopenia, giant splenomegaly, generalized lymphadenopathy, multiple lesions in lungs and febrile neutropenia was admitted to clinic R.Gorbacheva Memorial Institute with preliminary diagnosis of unverified hemoblastosis in March 2016. The initial diagnosis was suspected based on above mentioned characteristic clinical symptoms and laboratory data (Table 2-5). Analysis demonstrated moderate anemia, leukopenia and thrombocytopenia, slightly elevated transaminases and triglycerides, decreased fibrinogen and immunoglobulins. At the moment the most probable diagnosis consistent with laboratory findings was hematological disorder. Hypogammaglobulinemia at that time was explained as a consequence of lymphopenia and wasn't attributed to primary immunodeficiency. No cases of PID were reported in the family history. The child didn't previously suffer from recurrent or unusual or seasonal infections. At the age of 6 years, the patient had an episode of autoimmune hemolytic anemia which responded to Prednisolone treatment. Severe hemolytic anemia was the only registered autoimmune disorder phenomenon that never relapsed.

Diagnostic workup allowed to exclude bone marrow involvement. Bone marrow aspirate and trephine biopsy showed no signs of clonal proliferation or aplasia. Cytogenetic analysis of bone marrow demonstrated normal karyotype. Molecular-biologic analyses of genes associated with hemoblastosis (t8;21, inv16, t15;17, t9;22, FLT3, NPM1, WT1, EVI-1, MLL, $\mathrm{t} 4 ; 11$, del (1) SIL/TAL, $\mathrm{t} 1 ; 19, \mathrm{t} 9 ; 22, \mathrm{t} 12 ; 21)$ were negative. Lymphoproliferative disorder was suspected as a possible primary diagnosis due to generalized lymphadenopathy and splenomegaly. 
Table 2. Blood counts in the patient

\begin{tabular}{|c|c|c|c|c|c|}
\hline Laboratory parameters & 29.04.16 & 30.04 .16 & 01.05 .16 & units & Reference range \\
\hline Red blood cells(RBC) & 3.61 & 3.80 & 3.24 & *10^12/L & $(3.90-5.00)$ \\
\hline Hemoglobin (HGB) & 86 & 89 & 73 & $g / L$ & $(120-160)$ \\
\hline Hematocrit (HCT) & 25.4 & 26.9 & 22.2 & $\%$ & $(35.0-60.0)$ \\
\hline Mean Corpuscular Volume (MCV) & 70.4 & 70.7 & 68.6 & $\mathrm{fl}$ & $(80.0-99.0)$ \\
\hline Mean Corpuscular Hemoglobin (MCH) & 23.8 & 23.4 & 22.5 & $\mathrm{pg}$ & $(27.0-31.0)$ \\
\hline Mean Corpuscular Hemoglobin Concentration (MCHC) & 338 & 332 & 328 & $g / L$ & $(330-380)$ \\
\hline Leucocytes (WBC) & 1.2 & 1.3 & 1.0 & *10^9/L & $(4.0-9.0)$ \\
\hline Thrombocytes (PLT) & 28 & 32 & 30 & *10^9/L & $(180-320)$ \\
\hline Neutrophils (NE) \% & 51.0 & 58.1 & 54.2 & $\%$ & $(47.0-72.0)$ \\
\hline Neutrophils (NE) \# & 0.6 & 0.7 & 0.6 & *10^9/ת & $(2.0-5.5)$ \\
\hline Lymphocytes (LY) \% & 31.9 & 27.1 & 33.2 & $\%$ & $(19.0-37.0)$ \\
\hline Lymphocytes (LY) \# & 0.4 & 0.4 & 0.3 & *10^9/ת & $(1.2-3.0)$ \\
\hline Monocytes (M0) \% & 13.4 & 12.3 & 10.1 & $\%$ & $(3.0-11.0)$ \\
\hline Monocytes (M0) \# & 0.2 & 0.2 & 0.1 & *10^9/ת & $(0.1-0.6)$ \\
\hline Eosinophils (E0) \% & 2.9 & 1.9 & 1.8 & $\%$ & $(0.5-5.0)$ \\
\hline Eosinophils (E0) \# & 0.0 & 0.0 & 0.0 & *10^9/ת & $(0.0-0.3)$ \\
\hline Basophils (BA) \% & 0.8 & 0.6 & 0.7 & $\%$ & $(0.0-1.0)$ \\
\hline Basophils (BA) \# & 0.0 & 0.0 & 0.0 & *10^9/ת & $(0.0-0.1)$ \\
\hline
\end{tabular}

Table 3. Biochemical analysis of blood

\begin{tabular}{|l|l|l|l|l|}
\hline Biochemical parameters & $\mathbf{0 4 . 0 4 . 2 0 1 6}$ & $\mathbf{0 4 . 0 5 . 2 0 1 6}$ & Units & Reference range \\
\hline C-reactive Protein & 7.00 & 0.60 & $\mathrm{mg} / \mathrm{L}$ & $(0.01-5.00)$ \\
\hline Total Protein & 56.90 & 70.20 & $\mathrm{~g} / \mathrm{L}$ & $(57.00-80.00)$ \\
\hline Albumin & 36.00 & 44.40 & $\mathrm{~g} / \mathrm{L}$ & $(35.00-52.00)$ \\
\hline Creatinine & 0.077 & 0.067 & $\mu \mathrm{mol} / \mathrm{L}$ & $(0.044-0.088)$ \\
\hline Total Bilirubin & 20.00 & 17.00 & $\mathrm{mmol} / \mathrm{L}$ & $(5.00-21.00)$ \\
\hline Sodium & 138.30 & 135.0 & $\mathrm{mmol} / \mathrm{L}$ r & $(136.00-146.00)$ \\
\hline Potassium & 3.97 & 3.56 & $\mathrm{mmol} / \mathrm{L}$ & $(3.50-5.10)$ \\
\hline Aspartate aminotransferase & 74.20 & 69.7 & $\mathrm{U} / \mathrm{L}$ & $(0.00-35.00)$ \\
\hline Alanine aminotransferase & 29.80 & 31.2 & $\mathrm{U} / \mathrm{L}$ & $(0.00-35.00)$ \\
\hline Triglycerides & 3.5 & 3.3 & $\mathrm{mmol} / \mathrm{L}$ & $(0.55-3.21)$ \\
\hline Fibrinogen & 1 & 1.1 & $\mathrm{~g} / \mathrm{L}$ & $(1.7-4.0)$ \\
\hline
\end{tabular}

Table 4. Blood Level of Immunoglobulins

\begin{tabular}{|l|l|l|l|l|l|}
\hline & 04.04 .2016 & 21.04 .2016 & 04.05 .2016 & Units & Reference range \\
\hline Immunoglobulin A & 0.21 & 0.17 & 0.18 & $g / L$ & $(0.80-4.50)$ \\
\hline Immunoglobulin M & 0.64 & 0.27 & 0.27 & $g / L$ & $(0.50-3.00)$ \\
\hline Immunoglobulin G & 3.17 & 2.38 & 2.69 & $g / L$ & $(7.50-15.60)$ \\
\hline
\end{tabular}


Table 5. Immunophenotyping of lymphocytes

\begin{tabular}{|c|c|c|c|}
\hline 8.04.2016 & $\%$ & & Reference range \\
\hline CD3+ & 84.9 & $\uparrow$ & $63-69$ \\
\hline $\mathrm{CD} 4+$ & 54,9 & $\uparrow$ & $39-47$ \\
\hline $\mathrm{CD} 8+$ & 23.9 & & $23-29$ \\
\hline CD19+ & 10.2 & & $10-14$ \\
\hline CD56+ & 4.0 & $\downarrow$ & $6-17$ \\
\hline \multicolumn{4}{|l|}{ 15.06.2016 } \\
\hline CD27+lgM-lgD- (switched memory B cells) & 0.48 & $\downarrow$ & $1.00-43.00$ \\
\hline $\mathrm{CD} 27+\lg M+\lg D+$ & 0.39 & $\downarrow$ & $2.00-28.00$ \\
\hline CD27+lgM+lgD- & 0.00 & $\downarrow$ & $0.50-7.00$ \\
\hline $\mathrm{CD} 27-\lg M+\lg \mathrm{D}+$ & 6.86 & $\downarrow$ & $49.00-100.00$ \\
\hline
\end{tabular}

Giant splenomegaly with hypersplenism that resulted in life-threatening severe pancytopenia were indications for splenectomy with dissection of enlarged regional lymph nodes. It appeared to be a therapeutic and diagnostic option. Splenectomy performed at $5^{\text {th }}$ May 2016 was followed by recovery of peripheral blood counts, but hypogammaglobulinemia still persisted despite normal lymphocyte counts (See Fig. 1 for dynamics of immunoglobulins and lymphocytes). After splenectomy, total number of lymphocytes raised above 1000 cells per mcL, and all major lymphocyte subpopulations raised to normal ranges (number of CD4+ > 300 cells per mcL; number of CD8+ cells > 250 per $\mathrm{mcL}$, number of CD19+ cells $>170$ per $\mathrm{mcL}$, and number of CD56+ cells $>70$ cells per $\mathrm{mcL}$ ).

Histological and immunohistochemical analysis of removed spleen and lymph nodes demonstrated non-specific reactive changes that were not associated with any malignant disease (revised by 2 independent pathologists: Prof. V. V. Baykov and Prof. U. A. Krivolapov). Presence of enterovirus and Herpes simplex type $1 / 2$ virus was shown in spleen and lymph nodes by PCR assays and confirmed by immunohistochemistry. Blood samples were negative for viral, bacterial and fungal infections.

CT scanning prior to splenectomy revealed generalized lymphadenopathy of mediastinal and abdominal lymph nodes (Fig. 2A), and multiple lesions in lungs (Fig. 2B). Repeated microbiological cultures of bronchoalveolar lavage still were negative for bacterial, viral and fungal pathogens.

Since the patient has recently travelled to Egypt, visceral leishmaniosis was also suspected, due to fever, hepatosplenomegaly and pancytopenia evolving after the trip. However, hypogammaglobulinemia (instead of hypergammaglobulinemia typical to leishmaniosis), negative serological and PCR results, as well as absence of leishmania species in bone marrow aspirate allowed to rule out this diagnosis.

Time Course of Lymphocyte Counts and Ig G

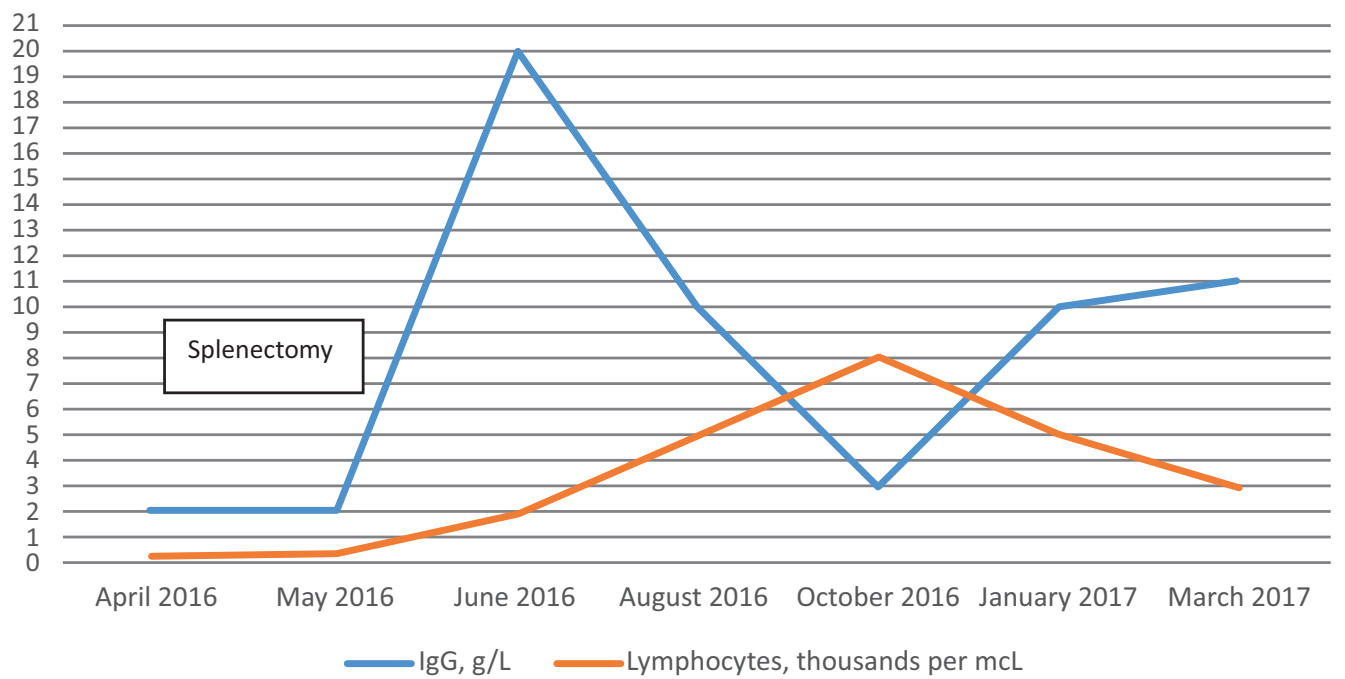

Figure 1. Time course of lymphocyte counts (x10 per $\mu \mathrm{L})$, and IgG levels $(g / L)$ 

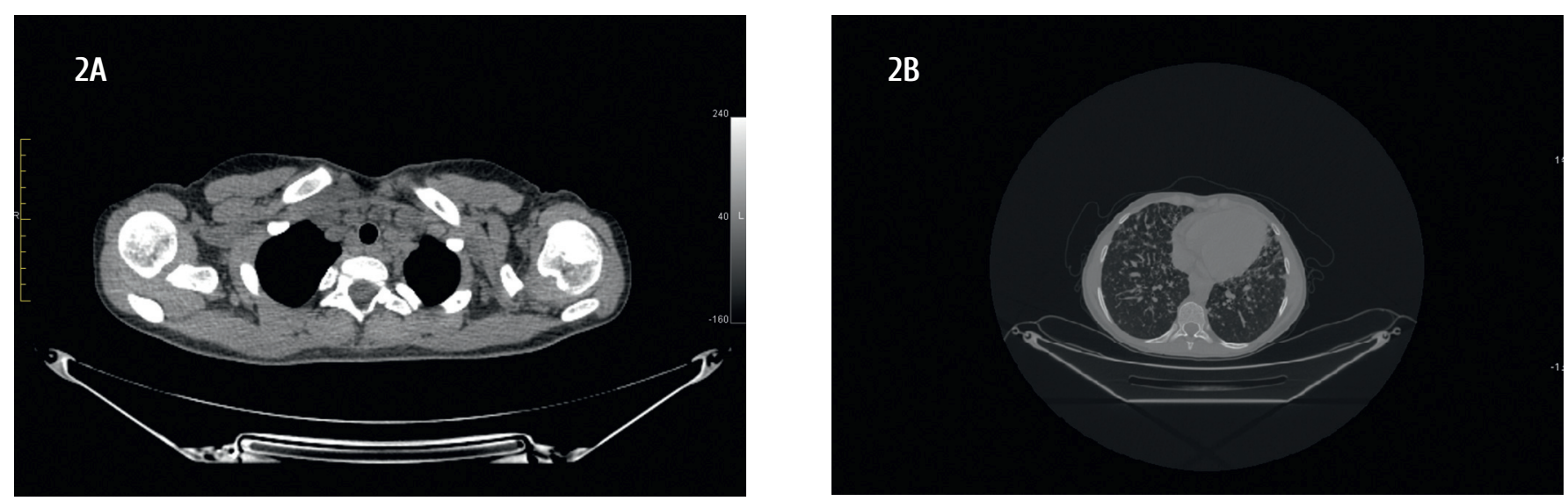

Figure 2. Computer tomography scans of mediastinal structures (2A) and lungs (2B)

A, mediastinal lymphadenopathy with enlarged lymph nodes marked with black arrows.

$\mathrm{B}$, multiple lesions in lungs in a patient with CVID. Numerous chaotic lesions (maximal size of 12x10 mm) are registered in lungs, with indefinite margins and peribronchial wall thickening. Subpleural triangular or polygonal spots, presumably of inflectional origin. Diffuse intensification of interstitial component.

The diagnostic search also included Gaucher disease. Analysis of glucocerebrosidase activity in blood was performed at the Research Centre for Medical Genetics (Russian Academy of Sciences, Moscow). The enzyme activity was within reference ranges, without a decrease typical to this genetic disorder.

The patient remained diagnostically unclear. There was no definitive evidence of malignancy, thus three non-malignant disorders were considered in differential diagnosis at the moment. They included: hemophagocytic lymphohistiocytosis (HLH), autoimmune lymphoproliferative syndrome (ALPS), and a primary immunodeficiency (PID). All these diseases share joint clinical signs and pathogenic mechanisms, being attributed to a common class of primary immunodeficiency syndromes [10].

HLH is a real problem for health care providers, in terms of diagnostic and therapeutic issues. Our patient had four criteria consistent with HLH: fever, splenomegaly, cytopenia and hypertriglyceridemia with hypofibrinogenemia (Tables 2 and 3). Hemophagocytosis in bone marrow or spleen, hyperferritinemia and $\mathrm{HLH}$-specific mutations were absent (PRF1, STXBP2, STX1, UNC13D), NK-cell activity in peripheral blood was normal. To establish diagnosis, according to Revised Diagnostic Guidelines for HLH, at least five of diagnostic criteria should be fulfilled, or HLH mutations should be present [11]. Hence, HLH was dismissed because only 4 criteria were present in the patient.

Autoimmune lymphoproliferative syndrome (ALPS) is characterized by malfunction in apoptosis of lymphocytes that leads to excessive lymphoproliferation. Presence of lymphadenopathy and splenomegaly, hemolytic anemia in previous history are characteristic to ALPS, but low level of double-negative CD3+/CD8-/CD4-/TCR $\alpha \beta+$ mature lymphocytes in peripheral blood was not consistent with this diagnosis. Mutations in FAS gene were not found upon whole genome sequencing (University of Dusseldorf, see data in Appendix). Absence of double-negative $\mathrm{T}$ lymphocytes and mutations in FAS gene made the diagnosis of ALPS very unlikely.
Due to severe persistent hypogammaglobinemia in the patient, a work-up for CVID was done. Absolute count of switched memory B-cells was checked $(0.48 \%)$, and it proved to be decreased (reference range 1-40\%) that is consistent with diagnosis of CVID (Table 5).

The whole exome sequencing of the patient leukocytes has been performed at University of Dusseldorf using the primary Immunodeficiency gene panel. The screening did not reveal any candidate genes considered related to primary immunodeficiency, autoimmune lymphoproliferative disorder, HLH or inherited lung disorders (Table 6).

\section{Discussion}

According to the established clinical criteria (Table 1), a CVID diagnosis was confirmed, based on persisting hypogammaglobulinemia, decreased count of switched memory B-cells (CD27+IgM-IgG-), autoimmune complications (hemolytic anemia) and non-malignant lymphoproliferative syndrome. Lung involvement shown in the child may occur in $30 \%$ of patients with CVID, being an unfavorable prognostic sign. Sarcoid-like granuloma, organizing pneumonia, lymphocytic interstitial pneumonitis and nonspecific interstitial pneumonia are the most common types of histological findings in affected lungs of CVID patients [13].

Hence, the CVID diagnosis is based on constellation of several non-specific criteria, while excluding other, less probable, clinical conditions.

The patient is now receiving regular infusions of intravenous immunoglobulins and level of immunoglobulin $\mathrm{G}$ is maintained at normal values. However, pulmonary complications of CVID still persist and slowly diminish with time. Lung biopsy has been performed, demonstrating granulomatous pneumonitis without any signs of malignancy. Immunosuppression with Rituximab was initiated due to progressing autoimmune problems and respiratory failure. The granulomatous pneumonitis is currently the only one and leading autoimmune disorder in the patient. 
Table 6. Genetic background of CVID, ALPS and HLH [12]

\begin{tabular}{|c|c|}
\hline Type of Disorder & Pathogenetic subtype \\
\hline $\begin{array}{l}\text { Common variable immunodeficiency and related } \\
\text { disorders. }\end{array}$ & $\begin{array}{l}\text { a. Common variable immunodeficiency of unknown origin, locus unknown. } \\
\text { b. ICOS (inducible T-cell costimulator) deficiency, gene - ICOS, locus - 2q33 } \\
\text { c. CD19 deficiency, locus - 16p11.2 } \\
\text { d. CD20 deficiency, gene - MS4A1, locus - 11q12.2 } \\
\text { e. CD81 deficiency, locus - 11p15.5 } \\
\text { f. TACI deficiency, gene - TNFRSF13B, locus - 17p11.2 } \\
\text { g. BAFF receptor deficiency, gene - TNFRSF13C, locus - 22q13.2 } \\
\text { h. CD21 deficiency, locus - 1q32.2 } \\
\text { i. CD27 deficiency, gene - TNFRSF7, locus - 12p13.3 } \\
\text { j. LRBA deficiency, gene - LRBA, locus - 4q13 }\end{array}$ \\
\hline Autoimmune lymphoproliferative disorder. & $\begin{array}{l}\text { a. ALPS-FAS (defective CD95), gene - FAS orTNFRSF6, locus - 10q23.31 } \\
\text { b. ALPS-FASL (defective CD178), gene - FASL or TNFSF6, locus - 1q24.3 } \\
\text { c. ALPS-CASP10, Caspase 10 deficiency, gene - CASP10, locus - 2q33.1 } \\
\text { d. CEDS (caspase } 8 \text { deficiency state), gene - CASP8, locus - 2q33.1 } \\
\text { e. RALD (Ras-associated autoimmune leukoproliferative disorder), } \\
\text { gene - NRAS, locus - 1p13.2 } \\
\text { f. V-KI-RAS2 Kirsten, gene - KRAS, locus - 12p12.1 }\end{array}$ \\
\hline $\begin{array}{l}\text { Familial Hemophagocytic lymphohistiocytosis } \\
\text { (FHL) }\end{array}$ & $\begin{array}{l}\text { a. FHL1. FHL with unknown gene defect. } \\
\text { b. FHL2 due to perforin defi ciency, gene - PRF1, locus - 10q22. } \\
\text { c. FHL3 UNC13D (Munc 13-4) deficiency, gene - UNC13D, locus - 17q25.3 } \\
\text { d. FHL4 due to syntaxin } 11 \text { deficiency, gene - STX11, locus - 6q24.2 } \\
\text { e. FHL5 due to syntaxin } 11 \text { binding protein } 2 \text { (Munc 18-2) deficiency, } \\
\text { gene - STBP2, locus - 19p13.2 } \\
\text { f. X-linked lymphoproliferative syndrome (type 1, XLP1), gene - SH2D1A, } \\
\text { locus - Xq25 } \\
\text { g. X-linked lymphoproliferative syndrome type } 2 \text { (XLP2), gene - XIAP, } \\
\text { locus - Xq25 } \\
\text { h. Immunodefi ciency X-linked, with magnesium defect, EBV infection and } \\
\text { neoplasm (XMEN), gene - M AGT1, locus - Xq21.1. } \\
\text { i. IL2 inducible T-cell kinase (ITK) deficiency, gene - ITK, locus - 5q33.3. }\end{array}$ \\
\hline
\end{tabular}

Prognosis for the presented patient is uncertain due to progressive lung involvement. Further treatment options may consist of glucocorticosteroids, cyclosporine A, sirolimus, cyclophosphamide, hydroxychloroquine, azathioprine, methotrexate, etanercept, infliximab and other immunosuppressive agents. If further respiratory deterioration will occur despite immunosuppressive treatment and IVIG, allogeneic hematopoietic stem cell transplantation and lung transplantation may be considerable options in this patient.

\section{Conclusion}

The present case report describes a 10-year old girl with major internationally approved criteria of common variable immunodeficiency (CVID), and specific lung involvement. Malignant conditions were excluded. NGS genetic study did not detect any gene mutation which could be responsible for CVID or related syndromes (ALPS, HLH). Hence, the CVID remains a diagnosis of exclusion, the attending doctor should suspect PID in clinical settings in cases of hypogammaglobulinaemia, non-specified lymphoproliferation, autoimmune features and absence of malignant disorder.

\section{Acknowledgements}

The authors are much appreciated to Dr. Ute Fischer from the University of Düsseldorf (Germany) who performed whole exome sequencing in this patient, and to thank Dr. Polina Stepensky from Hadassah Medical Center, Jerusalem (Israel) for valuable advices on this diagnostic procedure for the patient.

\section{Conflicts of interest}

No conflict interests are declared.

\section{References}

1. Vořechovský I, Cullen M, Carrington M, Hammarström L, Webster ADB. Fine mapping of IGAD1 in IgA deficiency and common variable immunodeficiency: identification and characterization of haplotypes shared by affected members of 101 multiple-case families. J Immunology. 2000; 164:4408-4416.

2. Maffucci P, Filion C A, Boisson B, Itan Y, Shang L, Casanova J L, Cunningham-Rundles C. Front Immunol. 2016; (7):220. 
3. Glocher E, Ehl S, Grimbacher B. Common variable immunodeficiency in children. Current opinion in pediatrics. 2007; 19:685-692.

4. Vukic EJ, Cunningham-Rundles C. Common variable immunodeficiency in children: clinical and immunological features of patients diagnosed before the age of 13. J Allergy Clin Immunol. 2004: 113(2), S39.

5. Salzer U, Warnatz K, Hartmut PH. Common variable immunodeficiency - an update. Arthritis Research \& Therapy. 2012:14:223.

6. Aleinikova OV, Fedorova AS, Sharapova SO. Should allogeneic hematopoietic stem cell transplantation be a treatment option for patients with Nijmegen breakage syndrome? Belarusian experience. Cell Ther Transplant. 2015; 4(1-2):31-36.

7. Gompels MM, Hodges E, Lock RJ, Angus B, White H, Larkin A, Chapel HM, Spicett GP, Misbah SA, Smith JL. Lymphoproliferative disease in antibody deficiency: a multi-centre study, Associated Study Group. Clin Exp Immunol. 2003; 134(2): 314-320.

8. Busse PJ, Farzan S, Cunningham-Rundles C. Pulmonary complications of common variable immunodeficiency. Ann Allergy Asthma Immunol. 2007;98(1):1-8; quiz 8-11, 43.
9. Kaveri SV, Maddur MS, Hegde P, Lacroix-Desmazes S, Bayry J. Intravenous immunoglobulins in immunodeficiencies: more than mere replacement therapy. Clin Exp Immunol. 2011;164 Suppl 2:2-5.

10. Al-Herz W, Bousfiha A, Casanova J-L, Chatila T, Conley M E, Cunningham-Rundles C, Etzioni A, Franco JL, Gaspar HB, Holland SM, Klein C, Nonoyama S, Ochs HD, Oksenhendler E, Picard C, Puck JM., Sullivan K, Tang MLK. Primary immunodeficiency diseases: an update on the classification from the International Union of Immunological Societies Expert Committee for Primary Immunodeficiency. Front Immunol. 2014; 5:162.

11. Henter JI, Horne A, Aricó M, Egeler RM, Filipovich AH, Imashuku S, Ladisch S, McClain K, Webb D, Winiarski J, Janka G. HLH-2004: Diagnostic and therapeutic guidelines for hemophagocytic lymphohistiocytosis. Pediat Blood Cancer. 2007;48(2):124-131.

12. Ochs D. Hans et al. Primary Immunodeficiency diseases. A Molecular and Genetic Approach (3rd Edition). 2014. Publisher: Oxford University Press.

13. Prasse A, Kayser G, Warnatz K. Common variable immunodeficiency-associated granulomatous and interstitial lung disease. Curr Opin Pulm Med. 2013;19(5):503-509.

\title{
Общая вариабельная иммунная недостаточность у ребенка. Описание клинического случая
}

\author{
Андрей В. Козлов, Татьяна А. Быкова, Анастасия С. Боровкова, Мария Ю. Аверьянова, Варвара Н. Овечкина, \\ Елена В. Морозова, Людмила С. Зубаровская, Николай Н. Мамаев, Борис В. Афанасьев \\ НИИ детской онкологии, гематологии и трансплантологии им. Р. М. Горбачевой; кафедра гематологии, трансфузиоло- \\ гии и трансплантологии, Первый Санкт-Петербургский государственный медицинский университет им. И. П. Павлова, \\ Санкт-Петербург, Россия
}

\section{Резюме}

Пациенты с синдромами первичного иммунодефицита встречаются относительно редко и им часто ставится ошибочный диагноз в связи с неспецифическими клиническими симптомами, напоминающими другие, более частые заболевания. Частота общей вариабельной иммунной недостаточности (ОВИН): 1 случай на 30.000 жителей Европы. Обычно имеется задержка в несколько лет между началом заболевания и диагнозом. Общая вариабельная иммунная недостаточность является наиболее частым первичным иммунодефицитом в возрасте старше 4 лет. Основным симптомом для установления диагноза является гипогаммаглобулинемия.

Целью данной статьи является показать существующие тенденции в диагностике ОВИН. Представленный клинический случай описывает 10-летнюю девочку, позитивную по четырем международ- ным клиническим критериям ОВИН и с наличием специфического поражения легких. При этом были исключены злокачественные заболевания. Генетическое исследование методом глубинного генного секвенирования (NGS) не выявило какой-либо генной мутации, которая могла бы быть ответственной за ОВИН или родственные синдромы (ALPS, HLH). Таким образом, ОВИН остается диагнозом исключения. У нашего пациента, несмотря на заместительную терапию внутривенным иммуноглобулином, легочная функция продолжала ухудшаться, что привело к необходимости приступить к иммуносупрессивной терапии.

\section{Ключевые слова}

Первичный иммунодефицит, общая вариабельная иммунная недостаточность, диагностические критерии, аутоиммунные осложнения. 